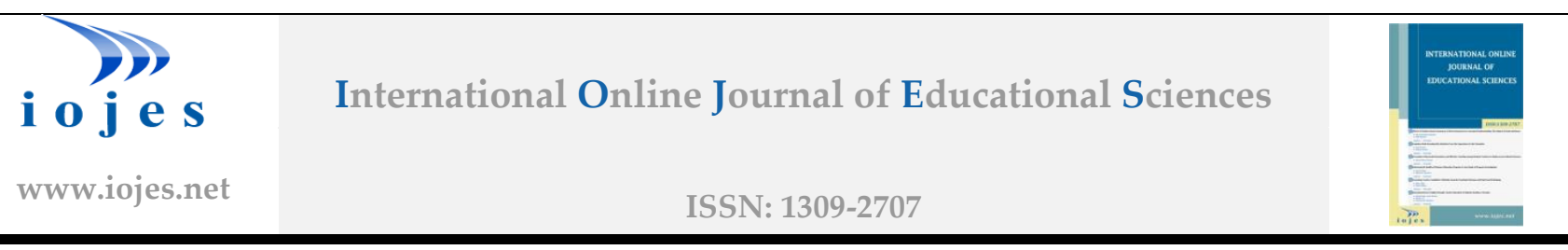

\title{
Metaphors of Higher Secondary Education Students' in TRNC Regarding the Concept of Turkish Cypriot Literature
}

\section{Research Article}

\author{
Esra KARAKAS KURT ${ }^{1}$, Ahmet PEHLIVAN ${ }^{2}$ \\ ${ }^{1}$ Cyprus International University, Faculty of Education, Department of Turkish Education, Cyprus, ORCID: 0000- 0002-9331-4759 \\ ${ }^{2}$ Eastern Mediterranean University, Faculty of Education, Department of Turkish Education, Cyprus, ORCID: 0000- 0002-5987-6475
}

To cite this article: Karakas-Kurt, E., \& Pehlivan, A. (2021). Metaphors of higher secondary education students' in TRNC regarding the concept of Turkish cypriot literature, International Online Journal of Educational Sciences, 13(1), 104-124.

\begin{abstract}
ARTICLE INFO
\section{ABSTRACT}

Article History:

Received: 08.06.2020

Available online:

01.02 .2021

This research aims to reveal TRNC Higher Secondary Education students' perception of Cypriot Turkish Literature via metaphors. For this purpose, students were asked to generate metaphors for "Turkish Cypriot Literature" class. Participants of the research consist of 787 students who attend 9th, 10th, 11th and 12th grades of ten schools which are administered by TRNC Directorate of General Secondary Education Administration and Directorate of Occupational Technical Education Administration. The research was based on Phenomenology pattern. Research data was gathered via two open-ended questions, which were selected by expert viewpoints and content analysis, which is a qualitative research method was used for the analysis of the collected data. As a conclusion of this research, thoughts and perceptions of students regarding Turkish Cypriot Literature was obtained and presented via metaphors. As a result, it is seen that Turkish Cypriot Literature was perceived as complicated, hard to grasp, boring and unbearable, never-ending and forever going on and ancestral, connected to the past. Despite these categories that reflect negative thoughts, categories of Turkish Cypriot Literature as; informative, educative, fun and pleasurable, comprehensive and varied, useful and needed, fluent and normative at the same time, rising curiosity and interest are also among the derived results. These metaphors that students generated give hints about the problems that exist in the education of literature and language. Students enabled us to understand what sort of education of literature and language they required via their positive and negative evaluations.
\end{abstract}

C 2021 IOJES. All rights reserved

Keywords:

Metaphor, Turkish Cypriot Literature, language and literature education.

\section{Introduction}

Use of a metaphor is an important acquisition, which arose from humankind's need to grasp the environment that he lives in and express it via language. Lakoff and Johnson (2005:28), puts forward that

${ }^{1}$ Corresponding author's address: Cyprus International Universty/Mersin, Turkey.

Telephone: 5338538999

e-mail: esra.karakas29@gmail.com, ekarakas@ciu.edu.tr

DOI: https://doi.org/10.15345/iojes.2021.01.007 
metaphor is not only an issue of language, but that thinking process of humankind is also metaphorical. Modell (2009:6-11) takes this thought as a base, and while presenting the relationship of metaphor with thought, he also emphasizes that it builds a bridge between knowledge and emotion. Metaphors, which are one of the most powerful intellectual means that build, direct and control our thoughts regarding how incidents occur and function, are described as "the language of experiences" as regards to the meaning they create for personal experiences (Miller, 1987: 219).

Metaphor is not only an art of language that is used to decorate the language; it is, at the same time, a tool to sense the world, a style of thinking. According to Morgan (1998: 14), use of metaphor is "a way of thinking and a viewpoint that infused in the way we comprehend the world". Metaphors, which inhold the mindset, value judgement and view of the life of the language and culture that they belong to, are conceptualized in universal aspects as well. Danesi (2017: 16) suggests that metaphor is the secrecy of literary expression in today's world, despite the reality that it is a feature of all languages.

Metaphors have been interpreting the outer world via a mental process. It provides the conceptualization of learning by building deep bonds within the memory. Reijos thinks that the actual aim of mental bonds that are built via metaphors is to create a familiarity of abstract concepts in our daily lives and to materialize them (As cited in Arslan-Bayrakçı, 2006: 102). Johnson (1987) stated that the main path, which enabled the creation of abstract thoughts, was using a metaphor by explaining the place of thoughts in life. Within the context of these viewpoints, it is possible to say that metaphors build a relation between the physical and mental skills of people and boost the permanence of knowledge.

Metaphors are available for use in various fields of education. Metaphors are used to in educational management, program development and planning and the improvement of creative thinking in education. Nevertheless, metaphors act as a tool for the evaluation of teaching practices and specifying the place of teaching within the concept of modern education (Vadeboncoeur \& Torres, 2003: 88; Pehlivan \& Aydın, 2010: 837).

Students act with their existing knowledge, skills, habits and attitudes in their repertoire while commenting on metaphors. According to Gibbs (1994), children are able to present things in new ways, via different ways of expression, by using their experiences and creative thoughts within the framework of daily conversations and incidents. In this context, metaphors could not be handled as isolated from the past experiences, pre-learnings and social environment of the individual, who generates them (Oğuz, 2005: 585587). The most important benefit of student metaphors is that they enable us to reach some information about the student. The student reflects his thoughts and ideas on the metaphor as well. For instance, researches on teacher candidates, in metaphors regarding the concept of "teacher", it is observed that the student-created his model and identity for a teacher. In studies, it is observed that metaphors were used as reliable tools of research in order to understand, reveal and interpret the mental images of teacher candidates as students, regarding the phenomenon of a student (Pehlivan \& Aydın, 2010: 849; Yılmaz, Göçen \& Yılmaz, 2013; Koç, 2014; Saban, 2009; Wells, 2015). Student metaphors may bring forward students' thoughts and emotions regarding certain subjects. Besides, depending on the metaphors that are generated, the expectations of students from the classes may be identified. New teaching environments may be designed for students to become more active in class.

Integrating metaphors may also be useful for literature teaching, which aims to keep the students in a balanced development in terms of hearing, thinking, and living.

Turkish Cypriot Literature (TCL) class did not exist in Cyprus before 2005. Instead, there was the Turkish literature class. TCL classes were included in the $9^{\text {th }}$ and $10^{\text {th }}$ Grade programs of high schools in Cyprus for the first time in parallel to the Turkish Literature class, as per the decision of the government of the day and related course books were written. Weekly credit of the class varied for the school types. The aim of this 
implementation, which was regarded as one of the innovations in the education system, was to put localization policies into practice (Pehlivan, 2007; Pehlivan, 2018). In the book, which was edited to identify the policies of Ministry of National Education (MNE) regarding Turkish Cypriot Education System, the reason for the inclusion of TCL class may be summarized as follows: TCL classes shall introduce Turkish Cypriot culture and literature to students; contribute to the recognition of the values of Turkish Cypriot people; point out the similarities with the Turkish Literature and contribute to the skill of students to perceive the differences between Turkish language and the Cypriot dialect ( KKTC MEB, 2006).

The objective of TCL class is primarily to provide students with the correct, elegant and effective use of Turkish and convey values or his work of TCL to them. Simultaneously, the enhancement of reading, speaking, listening and writing skills is also aimed with TCL education. Thus, students will improve their language awareness and enhance and value their native language the most. The primary target of this lesson in the education process is to educate individuals, who express themselves correctly in social life, think critical and creative, learn how to learn, take responsibilities, are entrepreneurs, harmonious with their environment; have the habit of researching, questioning and commenting, attained aesthetic pleasure and are sensitive for cultural values (KKTC MEB, 2006: 1-2).

In TCL, the culture, mindset and values of Turkish Cypriot society were introduced via literary works and conveyed with sample texts, to let individuals comprehend the formation of TCL, its place and significance in Turkish and World literature. Besides, the improvement of vocabulary was also paid attention to by reminding forgotten words in TC dialect, via texts.

The analysis of TCL1 coursebook shows that Turkish Cypriot Folk Literature works were included in it (KKTC MEB, 2006). All genres within the scope of folk literature were introduced via a comparative method. The phraseology that is unique to Cypriot dialect was preserved in texts and writings and styles of writers in the free reading texts were not changed. Analysis of TCL2 coursebook reveals the chronological aspect of TCL from the very beginning up till now. Historical periods, influences and genres were presented in detailed just as in Turkish Literature syllabus. It is seen that each period was sampled with at least three texts for analysis, which are qualified to reflect the literary genres. Periods that were analyzed within the scope of unique historical conditions and the selected texts that belong to those periods were tried to be comprehended via questions, explanations and assessments. The book consisted of two main sections; poetry and prose. In the poetry section, historical development of Turkish Cypriot poetry was analyzed and information regarding each period and movement was provided. In the prose section, information regarding types of prose was provided and all works, from the very early samples to the contemporary ones, were introduced chronologically (KKTC MEB, 2006).

In brief, since TCL will contribute to the development of the students in terms of culture, mother tongue, and life skills, it has been put into practice by the Ministry; therefore, it is important to investigate how TCL is perceived by students to achieve its purpose. For this reason;

\section{Purpose}

The purpose of this research is to determine the perception of students attending General Secondary Education Second Level and Occupational and Technical Education toward Turkish Cypriot Literature via metaphors. Moreover, focusing on metaphors can reveal the affective characteristics of the students about the Turkish Cypriot literature course through the metaphors produced by the students, and to contribute to the teachers and the curriculum, especially the "teaching process". 


\section{Method}

\section{Research Pattern}

This research is in the pattern of phenomenology (Yıldırım \& Şimşek, 2011: 72-75). Metaphor technique, which is one of the techniques of content analysis, was used for the data analysis of the research. In social sciences metaphors, which are used for gathering data, present robust and rich data regarding the related subject, incident and situation (Yıldırım \& Şimşek, 2011: 207-211). It is considered as an appropriate technique, particularly for describing perceptions of people towards specific learning (Palic \& Durukan, 2018).

In the research, stratified sampling method was used for determining the schools. This method is preferred in order to reveal and describe the properties of specific sub-groups that are referred to and to provide the opportunity for comparisons among them. It is possible to claim that this method is much more reliable than others in terms of providing representation (Büyüköztürk, Ş., Kılıç Çakmak, E., Akgün, Ö. E. Karadeniz, Ş., \& Demirel, E. 2009: 90-91).

\section{Sample /Study Group}

The general environment of the research is made up of $9^{\text {th }}, 10^{\text {th }}, 11^{\text {th }}$ and $12^{\text {th }}$ grade students who attend 31 schools that are administrated by Directorates of Northern Republic of Turkish Cypriot, Ministry of National Education General Secondary Education Administration and Occupational Technical Education Administration. In this study primarily, type of high schools which would be selected as sampling units have been divided into three homogeneous sub-groups, namely; general high schools, occupational high schools, and colleges which are medium of instruction in English.

Table 1. Total Number of Students in the Selected Schools and Number of Students who Participate in the Research

\begin{tabular}{|c|c|c|c|c|c|}
\hline $\begin{array}{l}\text { Type of } \\
\text { School }\end{array}$ & Name of the School & $\begin{array}{l}\text { Total } \\
\text { Number of } \\
\text { Students }\end{array}$ & $\begin{array}{l}\text { Number of } \\
\text { Participant } \\
\text { Students }\end{array}$ & Total & $\%$ \\
\hline \multirow{4}{*}{$\begin{array}{l}\text { General } \\
\text { High } \\
\text { School }\end{array}$} & Namık Kemal Lisesi & 674 & 111 & \multirow{4}{*}{366} & \multirow{4}{*}{46,50} \\
\hline & Bülent Ecevit Anadolu Lisesi & 546 & 81 & & \\
\hline & Lefkoşa Türk Lisesi & 649 & 95 & & \\
\hline & Anafartalar Lisesi & 779 & 79 & & \\
\hline \multirow{4}{*}{$\begin{array}{l}\text { Occupatio } \\
\text { nal High } \\
\text { School }\end{array}$} & Atatürk Meslek Lisesi & 512 & 79 & \multirow{4}{*}{292} & \multirow{4}{*}{$\% 37,10$} \\
\hline & Sedat Simavi End. Mes. Lisesi & 754 & 82 & & \\
\hline & Dr. Fazıl Küçük End. Mes. Lisesi & 398 & 56 & & \\
\hline & Güzelyurt Meslek Lisesi & 221 & 75 & & \\
\hline \multirow[b]{2}{*}{ College } & Türk Maarif Koleji & 645 & 73 & \multirow[b]{2}{*}{137} & \multirow[b]{2}{*}{17,40} \\
\hline & 19 Mayıs Türk Maarif Koleji & 411 & 64 & & \\
\hline TOTAL & & 5289 & 787 & 787 & 100 \\
\hline
\end{tabular}

According to table 1; breakdown of the total number of high schools is as follows; General high schools 46,50\%, Occupational high schools 37,10\% and Colleges 17,40\%. Schools that are included in the sampling were selected separately from each category, considering regions, via simple random sampling independently.

\section{Data Gathering Tools}

As the first step of study for the generation of data gathering tool, related researches, in which metaphors were used as a tool to put perceptions of individuals into action, were analyzed (Inbar, 1996; Balc1, 1999; Saban, 2004; Cerit, 2008; Saban, Koçbeker \& Saban, 2006; Yıldırım \& Şimşek, 2011; Miles \& Huberman, 2015). As a result of the literature scanning and expert opinions, a form of measurement was generated. The 
form consisted of two sections; the first section covers the personal information of the students, whereas the second section aims to determine perceptions toward the concept of TCL via metaphors. Data of the research was collected via the question; "Turkish Cypriot Literature is like ... Because it is ..." In this context, only the generation of metaphor is not sufficient; students are asked to put down their reasons for using that metaphor after the word "because", so that necessary data can be derived from it.

\section{Data Gathering Process}

Students were provided with necessary information regarding the creation of metaphor before the implementation was initiated. Principles of metaphor technique and some samples for the generation of visual and mnemonic metaphors were presented. Following the information and samples provided for metaphors, they were asked to answer the question in the following form; "Turkish Cypriot Literature is like ... Because it is ..." The environment was comfortable and students were given sufficient time for the creation of metaphors. The data source of the research is the hand-written papers which were completed within a duration of 2/3 of a lesson period by the students, who were among the sampling group.

\section{Data Analysis}

Research data was analyzed via content analysis technique. With this purpose, firstly the collected data was conceptualized, and then classified by the emerging concepts, and thus explanatory themes were identified. Collected data was read by two researchers and coded. During coding, data that were not in compliance with the logic of the metaphor were left out of scope. Metaphors created by students during the stage of the election were reconsidered and the purpose of use of each metaphor image was consulted. The ones, which lacked a consistent relation between the metaphor and the purpose of the use were excluded from the list. At the stage of categorization, data were categorized as per their common properties in accordance with their functions. For the comparison among experts, the formula of Miles and Humberman (1994); reliability $=$ number of agreements / (number of agreements + disagreements) was used. The consensus was above $90 \%$. As the metaphors were being categorized, resources, which existed in the literature (Inbar, 1996; Balc1, 1999; Saban, 2004; Cerit, 2008; Saban, 2006; Miles \& Huberman, 2015), were taken into consideration and, metaphors and created categories were re-evaluated by two expert intructors, apart from the researcher.

In order to attain the validity of reached results, data analysis stage was included in the method section in detail, and raw data was tried to be presented in the findings section as detailed as possible. Nevertheless, students' training on metaphors and availability of duration for self-expression increased the validity and reliability of the research. \% and frequency were used for the statistical analysis and evaluation of the data.

\section{Results}

In the research, the principle of "inner-convenience" was taken into consideration for the presentation of findings. Findings regarding metaphors which were created by students about the concept of "Turkish Cypriot Literature, were given in sub-headings via conceptual categories. Conceptual categories which were structured by considering theme integrity of metaphors were determined due to their intensity and put forward their perception toward language, literature and Turkish Cypriot Literature. At the end of each category, samples of that category were provided. The samples include the name of the school, class grade and sequence number of the student. Students' ability to create metaphors was shown in Table 2.

Table 2. Numbers of Turkish Cypriot Literature Metaphors That Students Created As Per The School Types

\begin{tabular}{lcccc}
\hline School Type & $\begin{array}{c}\text { Number of Students } \\
\text { Participated in the } \\
\text { Research }\end{array}$ & $\begin{array}{c}\text { Number of Students } \\
\text { Who Generated Valid } \\
\text { Metaphors }\end{array}$ & $\begin{array}{c}\text { Number of Students } \\
\text { Who Generated Invalid } \\
\text { Metaphors }\end{array}$ \\
\hline $\begin{array}{l}\text { Occupational } \\
\text { School }\end{array}$ & High & 295 & 183 & 112 \\
\hline
\end{tabular}




\begin{tabular}{lccc}
\hline General High School & 355 & 206 & 149 \\
\hline College & 137 & 88 & 49 \\
\hline Total & 787 & 477 & 310 \\
\hline
\end{tabular}

51 of 787 students, who participated in the research, did not answer the posed questions and was not able to generate a metaphor. Metaphors of students who belong to the group that generated invalid metaphors were not included in the scope of findings as they were not in compliance with the logic of metaphor. For example; Slimness of Jackle Turkish Cypriot Literature is like slimness of the jackle, because the language's complexness and hardness have been going on throughout the history (Occupational High School, 10th Grade, Technology of Machinery, male, 128). Turkish Pizza Turkish Cypriot Literature is like Turkish pizza because they are searched inside litter, and it is complicated and puzzling. (Occupational High School, 9th grade, male, 229).

Metaphors that students generated for the concept of "Turkish Cypriot Literature" were collected within 11 conceptual categories. Findings of TCL concept that students generated were shown in Table 3. In this table, there are also samples of metaphors that represent categories, which were described by students. Samples are given without any amendments in students'statements.

Table 3. Conceptual Categories and Descriptions of Metaphors Regarding the Concept of "Turkish Cypriot Literature "

\begin{tabular}{|c|c|c|c|}
\hline Conceptual & $\begin{array}{l}\text { Metaphor } \\
\text { samples }\end{array}$ & Total & Descriptions of Metaphor \\
\hline Categories & \multicolumn{3}{|c|}{$f$} \\
\hline $\begin{array}{l}\text { 1. Turkish Cypriot } \\
\text { Literature in the } \\
\text { Context of Being } \\
\text { Complicated and } \\
\text { Hard to Understand }\end{array}$ & $\begin{array}{l}\text { Soup (21), } \\
\text { Hair/Knot (6/4), } \\
\text { Riddle (7), } \\
\text { Sky (1), } \\
\text { Puzzle (1), } \\
\text { Book (1) }\end{array}$ & 106 & $\begin{array}{l}\text { "Literature is a hard and mind-exhausting thing just like a riddle" } \\
\text { (General high school, 9th grade, male, 187). , "Labyrinth is a lesson } \\
\text { that is consisted of various subjects and writers and that we have to } \\
\text { think about one point in order to grasp the subject." (Occupational } \\
\text { High School, } 11 \text { th grade, female, 371). "Cypriot Literature is like } \\
\text { a vegetable soup; it is complex as there are many vegetables in the } \\
\text { soup. In literature too, it is complex because there are subjects that } \\
\text { are similar to each other." (Occupational High School, 9th grade, } \\
\text { male, 227) "Literature of Cyprus is like a labyrinth; it is very } \\
\text { complicated. Nothing can be done without using the logic. You may } \\
\text { get out of it if only you know the way." (College, 10th grade science } \\
\text { group, female, 703). }\end{array}$ \\
\hline
\end{tabular}

\begin{tabular}{|c|c|c|c|}
\hline $\begin{array}{l}\text { 2. Turkish Cypriot } \\
\text { Literature in the } \\
\text { Context of Being } \\
\text { Fun }\end{array}$ & $\begin{array}{l}\text { Riddle (7), } \\
\text { Knot (4), } \\
\text { Flower (3), } \\
\text { Sky (1), } \\
\text { Puzzle (1), } \\
\text { Book (1) }\end{array}$ & 68 & $\begin{array}{l}\text { "Literature of Cyprus is like a riddle; because people start to get } \\
\text { pleasure out of it as they analyze and understand the course." } \\
\text { (College, 10th grade science group, male, 682). "Literature of } \\
\text { Cyprus is like the sky; because it consists of many beauties and } \\
\text { simultaneously the truth inside." (General high school, 10th grade } \\
\text { Turkish-Math (TM), female, 532). "Literature of Cyprus is like a } \\
\text { book; because our curiosity rises for other pages as we go on reading } \\
\text { and we get pleasure out of reading. CL also gets curious as it is } \\
\text { talked about. We want to talk about that lesson." (College, 10th } \\
\text { grade science, female, 766). "Literature of Cyprus is like a puzzle; } \\
\text { because its subjects, although they seem like in pieces, are inter- } \\
\text { connected and they give pleasure." (General high school, 9th grade, } \\
\text { female, 737). }\end{array}$ \\
\hline $\begin{array}{l}\text { 3. Turkish Cypriot } \\
\text { Literature in the }\end{array}$ & $\begin{array}{l}\text { Movie (9), } \\
\text { Hell (5), }\end{array}$ & 63 & $\begin{array}{l}\text { "Turkish Cypriot Literature is like a movie because many movies I } \\
\text { have watched are unnecessary and boring."(General high school, }\end{array}$ \\
\hline
\end{tabular}




\begin{tabular}{ll}
\hline Context of Being & Novel (3), \\
Boring, & Human (3), \\
Unnecessary and & Notebook(2), \\
Unlovable & Belt (1)
\end{tabular}

10th Grade, female, 454). "Turkish Cypriot Literature is like a belt; because it keeps squeezing and squeezing." (General high school, 11th Grade, science, male, 363). "Turkish Cypriot Literature is like a novel; it is long and boring like a novel. It is because it has neverending subjects; a boring lesson." (Occupational high school, 10th Grade, paediatrics, female, 53). "Turkish Cypriot Literature is like dry white beans; it is as tasteless and meaningless (General high school, 11th Grade, science, female, 448).

$\begin{array}{ll}\text { 4. Turkish Cypriot } & \text { Tree (7), } \\ \text { Literature in the } & \text { Flower (3), } \\ \text { Context of Scope } & \text { Sea (2), } \\ \text { and Variety } & \text { Cake(1) }\end{array}$

5. Turkish Cypriot

Literature in the

Informative,

Useful
Context of Being

Educative and
Tree (4),

Sun (2),

Encyclopedia(1)

Rainbow (1)

\section{7}

"Turkish Cypriot Literature is like the sea because subjects are so various that various subjects are discussed day by day. It is very different. We have subjects with in subjects. As sea unfolds, our subjects also do so, and it is a necessary lesson for us." (General high school, 10th Grade, TM, female, 522). "Turkish Cypriot Literature is like a cake; because there are many ingredients in it. When combined, these ingredients turn into a nice taste. It is sometimes the outer look of the cake that attracts us and sometimes the aroma inside." (College, 10th Grade, science, female, 679).

"Turkish Cypriot Literature is like the sun. The sun both burns and illuminates. Literature also both gives knowledge but is boring." (General high school, 10th grade, male, 205).

"Turkish Cypriot Literature is like a tree. The tree gives fruits all the time; it depends on the knowledge by making use of that fruit. (Occupational high school, 11th grade, female, 355).

53 "Turkish Cypriot Literature is like an encyclopedia because it is informative." (Occupational high school, 10th grade, motor vehicles and construction technician, female, 158).

"Turkish Cypriot Literature is like a rainbow because each section is of one colour, and each section consists of different knowledge. It is such a colourful lesson." (College and Anatolian High School, 10th grade, TM, female, 772).

"Turkish Cypriot Literature is like mud because when you go into it, you sink. But if you learn and understand what it is, you muddle through it. You can understand every subject if you study." (Occupational high school, 10th Grade, hairdressing and beauty, female, 264). "Turkish Cypriot Literature is like a poem because it

$\begin{array}{ll}\text { 6. Turkish Cypriot } & \text { Riddle (14), } \\ \text { Literature in } & \text { Mud (1), } \\ \text { Context of Being } & \text { Puzzle (2), } \\ \text { Complex/Complicat } & \text { Fair (1), } \\ \text { ed and Pleasing } & \text { Poem (1) }\end{array}$
is hard to write a poem, but when you write, a beautiful poem emerges. Turkish Cypriot Literature is a lesson that is hard to learn, but it is a lesson we love after we learn." (Occupational high school, 10th Grade, female, 520). "Turkish Cypriot Literature is like a fair because no matter how complex, it is enjoyable and fluent." (Occupational high school, 10th grade, metal machinery technology, male, 130). "Turkish Cypriot Literature is like puzzle because it is hard to grasp in the beginning, but when you understand and find what is where and how and bring pieces together, it becomes enjoyable." (College, 9th grade, female, 667).

"Turkish Cypriot Literature is like history because whenever we start to discuss Cypriot literature, beautiful living of the past is

$\begin{array}{ll}\begin{array}{l}\text { 7. Turkish Cypriot } \\ \text { Literature in the }\end{array} & \text { History (2), } \\ \text { Context of Being } & \text { Time Machine (1) } \\ \text { Based on the Past } & \end{array}$

21 talked about. There is not much left from the past for today. Everything is history." (Occupational high school, 11th Grade, Beauty and Hairdressing, female, 291). 
"Turkish Cypriot Literature is like a time machine because it tells about the period of poets a very long time ago." (General high school, 10th grade, language, male, 327).

\author{
8. Turkish Cypriot \\ Literature in the \\ Context of Being \\ Infinite and \\ Casette (1), \\ Repetitive
}

"Turkish Cypriot Literature is like a casette because it keeps repeating the same things." (Occupational high school, 10th grade, food-handicrafts, female, 72)

19 "Turkish Cypriot Literature is like a ballpoint pen because just when you think it is finished it starts writing again. The lesson is just like that. The names are just about to finish, and they start all over again." (General high school, 10th grade, TM, female, 502)

"Turkish Cypriot Literature is like a novel because it has subjects that are long and raising curiosity. As it is my country, I am curious about the incidents that happened in the past and the literary works that were written. It is a lesson that I participate in

9. Turkish Cypriot Literature in the Context of Rising Curiosity and Being Interesting
Novel (1), Cooking (1), Art (1)

18 attentively." (General high school, 10th grade, language, female, 337).

"Turkish Cypriot Literature is like cooking because as you do it or as you study, one likes it and feels curious." (General High School, 11th grade, IGCSE, female, 715). "Turkish Cypriot Literature is like art because the poetry and subjects that we analyze are impressive." (General high school, 12th grade, TM, female, 56).

"I resemble Turkish Cypriot Literature to a racing motor. Because the lesson passes by before we notice." (Occupational high school, 10th grade, motor vehicles and construction technician, male, 144). "Turkish Cypriot Literature is like water because the lesson is as fluent as water." (General high school, 9th grade, female, 18 308).

"Turkish Cypriot Literature is like the sea because it bears the influence of many cultures and literature. It is in constant change and flow." (General high school, 11th grade, science, female, 446). "Turkish Cypriot Literature is like football, because there are many rules." (College, 9th grade, male, 747).

"Turkish Cypriot Literature is like a flower because I love both. It is an enjoyable lesson. It does not require studying; it is a lesson that a local citizen of Cyprus can answer the questions. Its subjects 11. Turkish Cypriot Literature in the Context of Being a Necessity

Flower (1)

Sun (1)
5 are easy, and they are a must-know, and they should exist in our lives." (General high school, 11th grade, TM, female, 628).

"Turkish Cypriot Literature is like the sun because every living thing needs the sun. However, as any living thing needs the sun, we need it, too." (Occupational high school, 11th grade, beauty and hairdressing, female, 285).

\section{Total} 477

*Type of school, grade level and subject number of the student sample is provided inside the brackets.

In table 3; while 106 of the 477 metaphors constitute the category of "Turkish Cypriot Literature in the Context of Being Complicated and Hard to Understand", it is seen that the category of "Turkish Cypriot Literature in the Context of Being a Necessity" is represented by the least metaphor.

Detailed metaphor findings in each category are given below, respectively. 


\subsection{Turkish Cypriot Literature in the Context of Being Complicated and Hard to Understand}

In this category, we observed that students use metaphors by referring to complex and difficult-tounderstand TCL concepts. Table 3.1. presents the metaphors that constitute the category "Turkish Cypriot Literature in the Context of Being Complicated and Hard to Understand" and the number and percentage of students who stated each of the metaphors.

Table 3.1. Metaphors That Constitute the Category "Turkish Cypriot Literature in the Context of Being Complicated and Hard to Understand" and The Number and Percentage of Students Who Represent Them

\begin{tabular}{|c|c|c|c|c|c|c|c|c|}
\hline Metaphor & $f$ & $\%$ & Metaphor & $f$ & $\%$ & Metaphor & $f$ & $\%$ \\
\hline Aquarium & 1 &, 9 & 5 Fingers of aHand & 1 & ,9 & Music and Sound & 1 & ,9 \\
\hline Knot & 4 & 3,8 & Philosophy & 1 & ,9 & Jungle & 1 & 9 \\
\hline Arabic & 2 & 1,9 & Newspaper & 1 & ,9 & Puzzle & 2 & 1,9 \\
\hline Grape leaf & 1 & 9 & Jail & 1 & ,9 & Hair & 6 & 5,6 \\
\hline Like Me & 1 & 9 & Map & 1 & ,9 & Salad & 1 & 9 \\
\hline Computer Game & 1 & 9 & Life & 1 & ,9 & Looking for a needle in a & 1 & ,9 \\
\hline Never-Ending & 1 & ,9 & Human & 1 & ,9 & haystack & 2 & 1,9 \\
\hline Road & 1 & ,9 & String & 1 & ,9 & Ivy & 1 & 9 \\
\hline Broken Record & 7 & 6,6 & Ball of String & 1 & ,9 & Chess & 1 & 9 \\
\hline Riddle & 1 & ,9 & A Good Joke & 1 & ,9 & Vegetable Soup & 3 & 2,9 \\
\hline Büşra Nur & 1 & ,9 & Black Hole & 1 & ,9 & Poem & 1 &, 9 \\
\hline Mud & 1 & ,9 & Book & 3 & 2,9 & History & 1 & ,9 \\
\hline Bag & 1 & 9 & Necklace & 3 & 2,9 & Saw, The Movie & 1 & ,9 \\
\hline Chinese Torture & 21 & 19,8 & Necklace String & 1 & ,9 & Tourist & 3 & 5 \\
\hline Soup & 1 & 9 & Sand & 1 & ,9 & Vegetable Stew & 1 & ,9 \\
\hline Spaghetti & 1 & ,9 & Culture Magazine & 1 & 9 & Food & 1 &, 9 \\
\hline Notebook & 1 & ,9 & Labyrinth & 3 & 2,9 & Ball of Twine & 2 & 1,9 \\
\hline Sea & 1 & ,9 & Cabbage & 1 & ,9 & Brainbox & 1 & 9 \\
\hline Lesson & 1 & 9 & Pasta & 1 & ,9 & Chain & & \\
\hline Node & 1 & 9 & Math & 1 & ,9 & & & \\
\hline Earth & & & & & & & & \\
\hline
\end{tabular}

The analysis of Table 3.1 reveals that the category "Turkish Cypriot Literature in the Context of Being Complicated and Hard to Understand" is represented by a total 58 different metaphors and 106 students $(22,5 \%)$. Some of them may be named as; soup (21 students, $19,8 \%)$, riddle (7 students, $6,6 \%$ ), hair (6 students, $5,7 \%)$, knot (4 students, $4,7 \%$ ).

When these metaphors that were generated by students are analyzed, it is seen that TCL is perceived like a complicated riddle, computer game and labrinth that needs to be solved. As the student perceives TCL as covering a wide area and various subjects, he finds it complex and complicated. Students take TCL as a hard concept or lesson.

\subsection{Turkish Cypriot Literature in the Context of Being a Source of Fun and Pleasure}

In this category, we observed that students use metaphors for TCL that refer to the concepts of fun and enjoyment being a source of fun and entertainment and the number and percentage of students who have stated each metaphor.

Table 3.2. Metaphors That Constitute the Category "Turkish Cypriot Literature in Context of Being a Source of Fun and Pleasure" and The Number and Percentage of Students Who Represent Them

\begin{tabular}{lllllllll}
\hline Metaphor & $f$ & $\mathbf{\%}$ & Metaphor & $f$ & $\mathbf{\%}$ & Metaphor & $f$ & $\%$ \\
\hline Love & 1 & 1,5 & Sun & 1 & 1,5 & Clown & 1 & 1,5 \\
\hline
\end{tabular}




\begin{tabular}{lllllllll}
\hline PE Lesson & 1 & 1,5 & Something & 1 & 1,5 & Street Fair & 1 & 1,5 \\
Computer & 1 & 1,5 & Beautiful & 2 & 2,9 & Board & 1 & 1,5 \\
Game & 1 & 1,5 & Handball & 2 & 2,9 & Paris Hilton & 1 & 1,5 \\
Computer & 1 & 1,5 & Heart & 1 & 1,5 & Party & 1 & 1,5 \\
Crossword & 7 & 10,2 & Caterina & 1 & 1,5 & Cake & 1 & 1,5 \\
Riddle & 1 & 1,5 & Cat & 1 & 1,5 & Pizza & 1 & 1,5 \\
Heaven & 3 & 4,4 & Girl & 1 & 1,5 & Polygon & 1 & 1,5 \\
Flower & 1 & 1,5 & Book & 5 & 7,4 & Puzzle & 1 & 1,5 \\
Chocolate & 1 & 1,5 & Comedy Movie & 1 & 1,5 & Romantic Movie & 1 & 1,5 \\
Soup & 1 & 1,5 & Grit & 1 & 1,5 & Cute Sentence & 1 & 1,5 \\
Sea & 1 & 1,5 & L.O.L & 1 & 1,5 & History & 2 & 2,9 \\
Serial & 1 & 1,5 & Labyrinth & 1 & 1,5 & Documentary of & 1 & 1,5 \\
Movie & 1 & 1,5 & Lego & 1 & 1,5 & History & 1 & 1,5 \\
Football & 1 & 1,5 & Motor & 1 & 1,5 & Holiday & 2 & 2,9 \\
Ship & 1 & 1,5 & Music & 6 & 8,8 & Sweet & & \\
Rainbow & & & Game & & & & & \\
\hline
\end{tabular}

In this category, it is identified that students perceive "Turkish Cypriot Literature" as a source of fun and pleasure. The Analysis of Table 3.2 reveals that the category "Turkish Cypriot Literature in the Context of Being a Source of Fun and Pleasure" is represented by 47 different metaphors and 68 students (12,5\%). Some of the metaphors that form his category are as follows; riddle (7 students 10,3\%), game (6 students, $8,8 \%$ ) and comedy movies (5 students, 7,7\%).

Students of this category stated that they got pleasure out of TCL lessons, had enjoyable and fun moments and described TCL with concepts that they considered as fun.

\subsection{Turkish Cypriot Literature in the Context of Being Boring, Unnecessary and Unloved}

In this category, we observed that students use metaphors for TCL that refer to tedious and unnecessary concepts. Table 3.3. presents the metaphors that constitute the category "Turkish Cypriot Literature in the Context of Being Boring, Unnecessary and Unloved" and the number and percentage of students who stated each of the metaphors.

Table 3.3. Metaphors That Constituted the Category “Turkish Cypriot Literature in Context of Being Boring, Unnecessary and Unloved" and The Number and Percentage of Students Who Represent Them

\begin{tabular}{lllllllll}
\hline Metaphor & $f$ & $\mathbf{\%}$ & Metaphor & $f$ & $\mathbf{\%}$ & Metaphor & $f$ & $\mathbf{\%}$ \\
\hline Hot Paper & 1 & 1,6 & Dental Braces & 1 & 1,6 & Book & 1 & 1,6 \\
Adana Kebab & 1 & 1,6 & Elephant & 1 & 1,6 & Comedy Movie & 1 & 1,6 \\
Fire & 1 & 1,6 & Movie & 9 & 14,3 & Horror Movie & 2 & 3,2 \\
Headache & 1 & 1,6 & Galatasaray & 1 & 1,6 & Dry White Beans & 1 & 1,6 \\
Pepper & 1 & 1,6 & Monster & 1 & 1,6 & Problem & 1 & 1,6 \\
Empty Glass & 1 & 1,6 & Day & 1 & 1,6 & Novel & 3 \\
Blank Map & 1 & 1,6 & Ghost & 3 & 4,8 & Gum & 4,8 \\
Hell & 5 & 7,9 & Life & 2 & 3,2 & Hot Soup & 1,6 \\
Flower & 1 & 1,6 & Human & 3 & 4,8 & Theatre & 1 \\
Soup & 1 & 1,6 & Jelly & 1 & 1,6 & Sleep & 1,6 \\
Notebook & 2 & 3,2 & Head & 1 & 1,6 & Foof & 2 \\
Warehouse & 1 & 1,6 & Nightmare & 1 & 1,6 & & 1,6 \\
Lesson & 2 & 3,2 & Belt & 1 & 1,6 & & 1,6 \\
Outer Door & 2 & 3,2 & Water Pipe & 1 & 1,6 & & & 1 \\
& & & With Lime & & & & \\
\hline
\end{tabular}


In this category, it is identified that students perceived "Turkish Cypriot Literature" as boring and unnecessary. The analysis of Table 3.3 reveals that the category, "Turkish Cypriot Literature in the Context of Being Boring, Unnecessary and Unloved" was represented by a total 42 different metaphors and 63 students $(13,2 \%)$. Some of the metaphors that form this category are as follows; elephant (9 students, 14,3\%), hell (5 students, 7,9\%) and life (3 students, 4,8\%).

This category emphasizes that students do not love TCL. Students state that they were bored in the TCL lessons and consider TCL as unnecessary.

\subsection{Turkish Cypriot Literature in the Context of Scope and Variety}

In this category, we observed that students use metaphors for TCL that refer to scope and variety concepts. Table 3.4. presents metaphors that constitute the category, "Turkish Cypriot Literature in the Context of Scope and Variety" and the number and percentage of students who stated each.

Table 3.4. Metaphors that Constitute the Category, "Turkish Cypriot Literature in Context of Scope and Variety" and Number and Percentage of Students Who Represent Them

\begin{tabular}{lllllllll}
\hline Metaphor & $f$ & $\mathbf{\%}$ & Metaphor & $f$ & $\mathbf{\%}$ & Metaphor & $f$ & \% \\
\hline Tree Branch & 1 & 1,8 & Google & 2 & 3,5 & Classical Music & 1 & 1,8 \\
Tree & 7 & 12,3 & Rainbow & 2 & 3,5 & Citrus & 1 & 1,8 \\
Noah's Pudding & 1 & 1,8 & Sky & 1 & 1,8 & Ocean & 2 & 3,5 \\
Baloon & 1 & 1,8 & Orange of & 1 & 1,8 & University Exam & 1 & 1,8 \\
Bank Safe & 1 & 1,8 & Güzelyurt & 1 & 1,8 & Cake & 1 & 1,8 \\
Marsh & 1 & 1,8 & Map & 3 & 5,3 & Pizza & 1 & 1,8 \\
Computer & 1 & 1,8 & Human & 1 & 1,8 & Novel & 1 & 1,8 \\
Flower & 3 & 5,3 & Internet & 1 & 1,8 & Salad & 1 & 1,8 \\
Sea & 2 & 3,5 & Sealed Box & 1 & 1,8 & Ball Point Pen & 1 & 1,8 \\
Earth & 2 & 3,5 & Butterfly & 1 & 1,8 & Country & 2 \\
Tree of Life & 1 & 1,8 & BookReading a & 1 & 1,8 & Food & 3,5 \\
Universe & 1 & 1,8 & Book & 2 & 3,5 & Road & 1,8 \\
Movie & 1 & 1,8 & Sand & 2 & 3,5 & Trip & 1 & 1,8 \\
& & & Stairs & & & & 1
\end{tabular}

Analysis of Table 3.4 reveals that the category "Turkish Cypriot Literature in the Context of Scope and Variety" is represented by a total of 39 different metaphors and 57 students (11,9\%). Metaphors that constitute this category can be seen in the table. Some of these are as follows; tree ( 7 students, 12,3\%), flower ( 3 students, $5,3 \%$ ), sea (2 students, 3,5\%) and rainbow (2 students, 3,5\%).

In this category, TCL is regarded as an extensive and comprehensive lesson and concept. It is emphasized that the knowledge reaching today from the very early days of its initiation, is diverse and comprehensive. Students, who also stated that TCL was a structure of constant improvement and change, evaluated it in the context of comprehensiveness and diverseness; also emphasized its complexity and complication, which is a consequence of its comprehensiveness. It is claimed that the multifarious nature of TCL would not always be regarded positively.

\subsection{Turkish Cypriot Literature in the Context of Being Informative, Educative and Useful}

In this category, we observed that students use metaphors for TCL that refer to being informative, educative, and useful concepts. Table 3.5. represents the metaphors that constitute the category, "Turkish Cypriot Literature in Context of Being Informative, Educative and Useful" and the number and percentage of students who stated each. 
Table 3.5. Metaphors That Constitute the Category, "Turkish Cypriot Literature in Context of Being Informative, Educative and Useful" and the Number and Percentage of Students Who Represent Them

\begin{tabular}{|c|c|c|c|c|c|c|c|c|}
\hline Metaphor & $f$ & $\%$ & Metaphor & $f$ & $\%$ & Metaphor & $f$ & $\%$ \\
\hline Island & 1 & 1,9 & Movie (Love) & 1 & 1,9 & Streets of Cyprus & 1 & 1,9 \\
\hline Tree & 4 & 7,5 & Newspaper & 1 & 1,9 & History of Cyprus & 1 & 1,9 \\
\hline Encyclopedia & 1 & 1,9 & Past & 1 & 1,9 & Folk Songs of Cyprus & 1 & 1,9 \\
\hline Car & 1 & 1,9 & General & 1 & 1,9 & Book & 3 & 5,7 \\
\hline Driving & 1 & 1,9 & Knowledge & 1 & 1,9 & Music Box & 1 & 1,9 \\
\hline Fire & 1 & 1,9 & Lesson & 1 & 1,9 & River & 1 & 1,9 \\
\hline Moon & 1 & 1,9 & Rainbow & 2 & 3,8 & Vegetable & 1 & 1,9 \\
\hline Tool & 1 & 1,9 & Observation & 2 & 3,8 & Poem & 1 & 1,9 \\
\hline \multirow[t]{2}{*}{ Knowledge } & 1 & 1,9 & Rose & 1 & 1,9 & History & 2 & 3,8 \\
\hline & 3 & 5,7 & Sun & 1 & 1,9 & History Lesson & 1 & 1,9 \\
\hline Learning & 1 & 1,9 & Life & 1 & 1,9 & Holiday & 1 & 1,9 \\
\hline Knowledge & 2 & 3,8 & Story & 1 & 1,9 & Train & 1 & 1,9 \\
\hline Computer & 1 & 1,9 & Light & 1 & 1,9 & Tourist & 1 & 1,9 \\
\hline Cloud & 1 & 1,9 & Internet & 1 & 1,9 & Food & 1 & 1,9 \\
\hline Flower & & & Tiger & & & & & \\
\hline Old Times & & & Cyprus & & & & & \\
\hline Movie & & & & & & & & \\
\hline
\end{tabular}

Analysis of Table 3.5. reveals that the category, "Turkish Cypriot Literature in the Context of Being Informative, Educative and Useful" is represented by a total of 42 different metaphors and 53 students (11,1\%). Students regard "Turkish Cypriot Literature" concept as an informative and educative element. The metaphor that was used most in this category was a tree (4 students, 7,5\%). Other are as follows; computer and book ( 3 students, 5,7\%), flower, rose, sun and history ( 2 students, $3,8 \%$ ).

In this category, TCL is regarded as a lesson that is informative and educative, and one that supports improvement. The analysis of these metaphors, which were generated by students, reveals that TCL was regarded as an educative and informative lesson, however, that it may be boring for the students if they were overloaded.

\subsection{Turkish Cypriot Literature in the Context of Being Complex/Complicated and Pleasing}

In this category, we observed that students use the terms, complex and complicated interchangeably. Table 3.6 represents the metaphors that constitute the category, "Turkish Cypriot Literature in the Context of Being Complex/Complicated and Pleasing" and the number and percentage of students who stated each.

Table 3.6. Metaphors That Constitute the Category, "Turkish Cypriot Literature in Context of Being Complex/Complicated and Pleasing" and the Number and Percentage of Students Who Represent Them

\begin{tabular}{|c|c|c|c|c|c|c|c|c|}
\hline Metaphor & $f$ & $\%$ & Metaphor & $f$ & $\%$ & Metaphor & $f$ & $\%$ \\
\hline Opuntias & 1 & 2,0 & Guitar & 1 & 2,0 & Game & 2 & 4,1 \\
\hline Computer & 1 & 2,0 & Sun & 1 & 2,0 & Puzzle & 2 & 4,1 \\
\hline Riddle & 14 & 28,6 & Life & 2 & 4,1 & Painting & 1 & 2,0 \\
\hline Mud & 1 & 2,0 & Story Book & 1 & 2,0 & Novel & 1 & 2,0 \\
\hline Childhood Days & 1 & 2,0 & Human & 2 & 4,1 & Number & 1 & 2,0 \\
\hline Soup & 1 & 2,0 & My Girlfriend & 1 & 2,0 & Poem & 1 & 2,0 \\
\hline Sea & 1 & 2,0 & Labyrinth & 1 & 2,0 & Puzzle & 2 & 4,1 \\
\hline Ice Cream & 1 & 2,0 & Math Lesson & 1 & 2,0 & Food & 1 & 2,0 \\
\hline Knot & 1 & 2,0 & Mp 3 Player & 1 & 2,0 & Star & 1 & 2,0 \\
\hline \multirow[t]{2}{*}{ Fair } & 1 & 2,0 & School & 1 & 2,0 & Road & 1 & 2,0 \\
\hline & & & & & & Zuma Game & 1 & 2,0 \\
\hline
\end{tabular}


Analysis of Table 3.6 reveals that the category, "Turkish Cypriot Literature in the Context of Being Complex/Complicated and Pleasing" is represented by a total of 31 different metaphors and 49 students $(10,3 \%)$. In this category, mostly the metaphor riddle was used (14 students, $28,6 \%)$.

As per the analysis of students' metaphors, it is discovered that "Turkish Cypriot Literature" was regarded as a complex lesson, which may be managed if adequately studied and that students consider this situation as pleasing. Some students within the category regarded the lesson as difficult and complicated, however during the process, they stated that they found out that it was loveable and pleasing.

\subsection{Turkish Cypriot Literature in the Context of Being Based on Past}

In this category, we observed that students use the terms related to past concepts. Table 3.7. represents the metaphors that constitute the category of "Turkish Cypriot Literature in Context of Being Based on Past" and the number and percentage of students who stated each.

Table 3.7. Metaphors That Constitute the Category, "Turkish Cypriot Literature in Context of Being Based on Past" and the Number and Percentage of Students Who Represent Them

\begin{tabular}{lllllllll}
\hline Metaphor & $f$ & $\mathbf{\%}$ & Metaphor & $f$ & $\mathbf{\%}$ & Metaphor & $f$ & \% \\
\hline Tree & 1 & 4,8 & Old Stone & 1 & 4,8 & Adventure & 1 & 4,8 \\
Encyclopedia & 1 & 4,8 & Old Life & 1 & 4,8 & Novel & 1 & 4,8 \\
Antique & 1 & 4,8 & Movie & 1 & 4,8 & Poem & 1 & 4,8 \\
Mirror & 2 & 9,5 & Past & 1 & 4,8 & History & 2 & 9,5 \\
Flower & 1 & 4,8 & History of & 1 & 4,8 & History Lesson & 2 & 9,5 \\
Legend & 1 & 4,8 & Cyprus & 1 & 4,8 & Time Machine & 1 & 4,8 \\
\end{tabular}

Analysis of Table 3.7. reveals that the category, "Turkish Cypriot Literature in the Context of Being Based on Past" is represented by a total of 18 different metaphors and 21 students $(4,4 \%)$. In this group, three metaphors, namely; mirror, history and history lesson (2 students 9,5\%) were used twice, and others were used once. Metaphor samples were mostly identified with history and items that are based on it. Respondents have put light on the relation between literature and history of literature via metaphors that they used. Various samples of curiosity that one feels for his past and the hope for his future are seen in the metaphors of this group.

\subsection{Turkish Cypriot Literature in the Context of Being Infinite and Repetitive}

In this category, we observed that students use metaphors that refer to the concept of being infinite. Table 3.8. represents the metaphors that constitute the category, "Turkish Cypriot Literature in the Context of Being Infinite and Repetitive" and the number and percentage of students who stated each.

Table 3.8. Metaphors That Constitute the Category, "Turkish Cypriot Literature in Context of Being Infinite and Repetitive" and the Number and Percentage of Students Who Represent Them

\begin{tabular}{lllllllll}
\hline Metaphor & $f$ & $\mathbf{\%}$ & Metaphor & $f$ & $\mathbf{\%}$ & Metaphor & $f$ & \% \\
\hline Tree & 1 & 5,3 & Day & 1 & 5,3 & Hair & 5,3 & 1 \\
Encyclopedia & 1 & 5,3 & Cassette & 1 & 5,3 & Eternity & 1 & 5,3 \\
Car & 1 & 5,3 & Book & 2 & 10,5 & Dictionary & 1 & 5,3 \\
Soldier & 1 & 5,3 & Marathon Run & 1 & 5,3 & Wheel & 1 & 5,3 \\
Sea & 1 & 5,3 & Online Game & 1 & 5,3 & Theatre & 1 & 5,3 \\
Domino & 1 & 5,3 & Novel & 1 & 5,3 & Ball Point Pen & 1 & 5,3 \\
\hline
\end{tabular}

Analysis of Table 3.8. reveals that the category, "Turkish Cypriot Literature in the Context of Being Infinite and Repetitive" represented by a total of 18 different metaphors and 19 students (4\%). The metaphor of the book was used twice, and others were used once. 
In this category, TCL is perceived as infinite in terms of both its subjects and duration. Students state that the lessons and subjects never ended and that they were bored. In this category of which students' ideas might be evaluated as "negative", as it is emphasized that TCL is all about repetitions.

\subsection{Turkish Cypriot Literature in the Context of Rising Curiosity and Being Interesting}

In this category, we observed that students use metaphors that refer to curiosity and being interesting concepts. Table 3.9. represents the metaphors that constitute the category, "Turkish Cypriot Literature in the Context of Rising Curiosity and Being Interesting" and the number and percentage of students who stated each.

Table 3.9. Metaphors That Constitute the Category, "Turkish Cypriot Literature in Context of Rising Curiosity and Being Interesting" and the Number and Percentage of Students Who Represent Them

\begin{tabular}{lllllllll}
\hline Metaphor & $f$ & $\mathbf{\%}$ & Metaphor & $f$ & $\mathbf{\%}$ & Metaphor & $f$ & $\mathbf{\%}$ \\
\hline Car & 1 & 5,6 & Cyprus & 1 & 5,6 & Art & 5,6 & 1 \\
Fish & 1 & 5,6 & Cyprus Island & 1 & 5,6 & History Book & 1 & 5,6 \\
Girl & 2 & 11,1 & Book & 1 & 5,6 & Old Record & 1 & 5,6 \\
Riddle & 1 & 5,6 & Sphere & 1 & 5,6 & Cooking & 1 & 5,6 \\
Flower & 1 & 5,6 & Motor & 1 & 5,6 & & \\
Sea & 1 & 5,6 & Novel & 2 & 11,1 & & \\
\hline
\end{tabular}

Analysis of Table 3.8 reveals that the category, "Turkish Cypriot Literature in the Context of Rising Curiosity and Being Interesting" represented by a total of 17 different metaphors and 18 students (3,8\%). The metaphor of a girl was used twice, and others were used once.

In this category, it is stated that TCL is interesting, and it raised curiosity in terms of its periods and subjects. Nevertheless, it was also emphasized that TCL was impressive. TCL was described via concepts that imply curiosity, interest and favour.

\subsection{Turkish Cypriot Literature in the Context of Being Fluent and Normative}

In this category, we observed that students use metaphors that refer to the concept of fluent. Table 3.10. represents the metaphors that constitute the category, "Turkish Cypriot Literature in the Context of Being Fluent and Normative" and the number and percentage of students who stated each.

Table 3.10. Metaphors That Constitute the Category, "Turkish Cypriot Literature in Context of Being Fluent and Normative" and the Number and Percentage of Students Who Represent Them

\begin{tabular}{lllllllll}
\hline Metaphor & $f$ & \% & Metaphor & $f$ & $\mathbf{\%}$ & Metaphor & $f$ & $\%$ \\
\hline Basketball & 1 & 5,6 & Book & 2 & 11,1 & Water & 4 & 22,2 \\
Sea & 2 & 11,1 & Motor & 1 & 5,6 & Shampoo & 1 & 5,6 \\
Football & 1 & 5,6 & Motor & 4 & 22,2 & Road & 1 & 5,6 \\
Day & 1 & 5,6 & & & & & & \\
\hline
\end{tabular}

Analysis of Table 3.10. reveals that the category, "Turkish Cypriot Literature in the Context of Being Fluent and Normative" represented by a total of 10 different metaphors and 18 students (3,8\%). This category has an equal percentage of the TCL category in the context of rising curiosity and being interesting. In this category, metaphors of motor and water were used four times, metaphors of book and sea were used twice, and others were used once.

In this category, it is claimed that TCL, which bears the signs of social and cultural formation, is constantly in alteration and flow. Some of the students stated that they loved TCL and emphasized that it was 
fluent. To them, the course of the lesson and subjects are flowing like water. Nevertheless, it is stated that TCL was attached to some rules and that it was normative.

\subsection{Turkish Cypriot Literature in the Context of Being a Necessity}

In this category, we observed that students use metaphors that refer to the concept of necessity. Table 3.11. represents the metaphors that constitute the category, "Turkish Cypriot Literature in the Context of Being a Necessity" and the number and percentage of students who stated each.

Table 3.11. Metaphors That Constitute the Category, "Turkish Cypriot Literature in Context of Being a Necessity" and the Number and Percentage of Students Who Represent Them

\begin{tabular}{|c|c|c|c|c|c|c|c|c|}
\hline Metaphor & $f$ & $\%$ & Metaphor & $f$ & $\%$ & Metaphor & $f$ & $\%$ \\
\hline Flower & 1 & 20,0 & Wrestling & 1 & 20,0 & Motor & 1 & 20,0 \\
\hline Sun & 1 & 20,0 & Pigeon & 1 & 20,0 & & & \\
\hline
\end{tabular}

Analysis of Table 3.10. reveals that the category, "Turkish Cypriot Literature in the Context of Being a Necessity" represented by a total of 5 different metaphors and five students $(1 \%)$. This category of Turkish Cypriot Literature in the Context of Being a Necessity has the least metaphors and percentage. Metaphors that form this category were used once.

In this category, TCL is perceived as a requirement and necessity. Students stated that literature was necessary to them.

\section{Discussion and Conclusion}

In the conclusion of the research, it is surfaced that students perceive TCL as "complex, hard to understand, boring and unbearable, never-ending and on-going, a thing of past". In contrast with those categories, which stated negative thoughts, perception of TCL as "informative, educative, entertaining and pleasing, comprehensive and diverse, useful and necessary, fluent and interesting "are among the conclusions that contain positive thoughts. In a study, which was carried out with middle school students and Turkish language teacher candidates, metaphorical categories regarding Turkish lessons were determined to be getting pleasure, source of knowledge/learning and being identical to life and it was claimed that students regarded Turkish language lessons as a necessity (Dinçel \& Yllmaz, 2018: 270). The finding that lessons being regarded as a source of knowledge, useful, necessary and entertaining by the students is identical to researches that were carried out on other lessons. Research of Soysal ve Afacan (2012), regarding the concept of "science and technology lesson" and results of the research of Akça, Gültekin ve Çençen (2015) regarding the concept of "social sciences lesson" are supportive of the this finding.

As per the analysis of metaphors, which were used by General high school, Occupational high school and college high school students, regarding TCL concepts; it is revealed that some of the students regarded literature as complex and hard to understand. Reasons are that; texts and content that were studied during the class were hard to understand, failing to meet the requirements and interests of the student and not easily perceptible. In the study of Oral and Aşlıoğlu (2000: 37) on the evaluation of the perception of Turkish Language and Literature teachers on Turkish Language and Literature lesson more than half of the teachers stated that there was a medium-degree correlation between the objectives of the Turkish Language and Literature program and content of the lesson. Teachers also advocated that the interest for Turkish Language and Literature lesson was low. That is because the lesson consists of texts, and content that were not in compliance with the interest and desire of the students. Language and literature education emphasizes that students can only be provided with a robust consciousness of language and pleasure of reading via qualified literary texts. For instance, Kavcar (2017:111) stated that today's literature education was turned into a huge pile of knowledge and could not succeed further than raising a generation of "so-called people of culture". He 
also emphasized that language or literature lessons, which do not engrain critical viewpoint and analysis and are stuffed with dead, stock knowledge was dismissed by students. In this regard, instead of names, dates, movements; the principal objective should be providing students with good content, living with abundant and qualified texts and a taste of language and art. According to Aslan (2010) and (2017), texts which were discussed by teachers during the lessons should be available for the generation of different thoughts and critical and liberal thinking. Content of the lesson should be in a harmonious quality with the level of age and development, interest and admiration, and needs and lifestyles of the students. In the studies teachers' viewpoints about the literature lessons are supportive of the perceptions of students, who participated in this study, regarding the concept of TCL. The students participating in this research also emphasized the facts they produced both positively and negatively. So texts, which are the main tools of language education, shall be selected in compliance with the interest, requirement and environment of the language of the student; and enable the individual to undertake significant responsibilities within his universe of dreams and thoughts. The literary text, which provides individuals with the opportunity to make semantic deductions via dreaming, thinking and feeling, should be constructed with the means of Turkish expressions because providing the ability to use Turkish language attentively and consciously, is a significant stimulus to attain sensitivity and consciousness of language (Sever et al., 2011).

Among the reasons of negative attitude in the metaphors of the category, "Turkish Cypriot Literature in the Context of Being Boring, Unnecessary and Unloved", is that the literature lesson did not appeal to the students and subjects and the style of the lesson was boring. For instance, statements such as; "TCL is like a horror movie, because I get bored during the lessons and I don't like the teacher either", "TCL is like food, the teacher comes and talks; she leaves before I understand, which is like I finish eating my food and I am left with an empty plate." reveal the negative attitude. In this research, students perceiving literature as boring, tasteless, complicated, incomprehensible and infinite shows that the aimed interaction in terms of readers could not be provided either. In another study, it was observed that TCL lessons were not interesting for the students and the teaching approach of the lesson was the classical one (Pehlivan, 2007). Metaphors, which were generated by students in research regarding Turkish Language and Literature education, are supportive of this finding. In the research, it was determined by the metaphors that during Turkish Language and Literature lessons, texts were handled in a shallow manner. Thus students had difficulties in understanding and analyzing them; that their skills of reading comprehension were not improved; that particularly for poetry, they were not able to make sense of and comment on implicit expressions, images, symbols and associations, thus they had a prejudging approach to poetry; and for analysis of short stories all they were capable of was to write an abstract or list the elements like time, spot and characters (Kapanadze \& Kaya, 2019).

Another conclusion that expresses their negative views regarding the concept of literature is that students perceived TCL as a concept that is infinite and repetitive. Metaphors that constituted the category "Turkish Cypriot Literature in Context of Being Infinite and Repetitive" state that literature subjects and lessons were infinite and they are all about repetitions. This finding is similar to the findings of Erten's (2008: 267) work on the attitudes of students toward grammar lessons in secondary education. The research states that students perceived the lesson as complicated and incomprehensible and that they could not cope up with the lesson. In the conclusion of another research regarding Turkish Language and Literature teaching, it was stated that students' interest in the literature lessons and their motivation was very low. Also, they were very much bored in the class, the lesson was not effective as it was based on memorization, there was no participation in the class and that they took this lesson just for academic success and to increase their average point (Kapanadze \& Kaya, 2019). Research which analyzed metaphors of middle school students and Turkish language teacher candidates regarding the concept of "Turkish language lesson", the statements of students regarding the difficulty of the lesson, the repetitions in the curriculum, the dullness and unnecessity of the 
lesson reveal that some regulations should be carried out regarding the content and specifically the process of the Turkish language lessons (Dinçel \& Yılmaz, 2018: 281).

Such negative attitudes make us question how language and literature teaching should be implemented. It should be considered that these perceptions of students are not only toward the texts but the course of the lesson as well. A literature lesson which only discusses the texts in the coursebook was a part of the traditional education understanding. For a contemporary education of language and literature, it is required that the educational environment shall be constructed with qualified artistic stimuli which are supportive of the educational process. When qualified literary text is provided with other artistic stimuli, they will become the tools of an interactive educational environment, which appeal interest, loads the consciousness of responsibility and moves the world of dreams and thoughts. İpşiroğlu (2002:81) advocates that a contemporary language and literature education shall be constituted on a foundation of developing versatile and multi-dimensional intellectual skills via literary texts. She emphasizes that students may learn to think creatively and critically via literary and didactic texts, which are interesting and appropriate for them. Thus, sharing intellectual and influential texts suitable for students' interests and levels in the educational environment and their presence in textbooks can change students' negative perceptions (boring, unnecessary, endless, etc.).

With various teaching and learning activities which are realized within the process of language and literature education that provides students with both a national and a universal literary culture and let them encounter with qualified literary and didactic texts; not only reading but also writing, listening and speaking skills of the students would enhance. A contemporary language and literature education process shall be able to provide students with the ability to express their thoughts and feelings in both verbal and written forms. Nevertheless, students of a contemporary language and literature education process shall become individuals who are capable of listening to what others have to say and making effective evaluations, as a requirement of a democratic society (Çelik, 2013: 12).

As a conclusion, metaphors assist us to reveal the viewpoints of others and understand their thoughts and emotions. Levine (2005) emphasized this quality of metaphors in his work and stated that metaphors hold people's experiences of the past, ideas of today and hopes for the future. Kamberi (2014), in his study named "Using Metaphors in Language Teaching and Learning", stated that metaphors provided teachers with useful feedback in order to evaluate thoughts and emotions of the students in the language classes. Therefore, as the conclusion of the research, thoughts and perceptions of students regarding TCL were revealed via metaphors. These metaphors that were generated by students provide hints about the existing problems regarding the education of language and literature. Students enabled us to understand what kind of education of literature and language the required via their positive and negative evaluations.

In the study, we observed that students use some metaphors more than one category for different reasons. Students used the same metaphor in both positive and negative meanings. For example, while the metaphor of "novel" is expressed interesting and rising curiosity in some students, it is seen as a boring and unnecessary concept in others. This situation can be explained by the students' mindset, value judgments, worldview, interest, perception and personal development.

Negative perceptions of more than half of students, who participated in the study, reveal that the negative results of studies which are present in the literature continue and that the suggestions of researchers regarding literature education were not taken into consideration. Negative aspects which were stated in the studies shall be taken into consideration by the experts and the existing positive aspects shall be further improved. A literature education which is supported by technology, as well as the literary texts and contemporary educational environments that are in compliance with students' interests and requirements, shall be constituted so that they can express themselves freely, reveal their different skills in various ways and 
find their hidden aspects. Moreover, the topics in the curriculum topics should be reevaluated, and the textbooks should be rearranged in terms of text and activities. 


\section{REFERENCES}

Akça, N., B, Gültekin, F., \& Çençen, N. (2015). Sosyal bilgiler öğretmen adaylarının sosyal bilgiler dersine ve sosyal bilgiler öğretmenine ilişkin metaforları. Ahi Evran Üniversitesi Kırşehir Ĕgitim Fakültesi Dergisi, 16(1), 183-199.

Aslan, C. (2010). Düşünme becerilerini geliştirici dil ve edebiyat öğretimi ortamları- bir eğitim durumu örneği. Balıesir Üniversitesi Sosyal Bilimler Enstitüsü Dergisi, (13)24, 127-152.

Aslan, C. (2017). Türkçe - Türk dili ve edebiyatı öğretimi. Ankara: Anı Yayıncılık.

Arslan, M., \& Bayrakçı, M. (2006). Metaforik Düşünme ve Öğrenme Yaklaşımının Eğitim-Öğretim Açısından İncelenmesi. Millî Ĕ̆itim, 100-107.

Balc1, A. (1999). Metaphorical images of school: school perceptions of students, teachers and parents from four selected schools. Doctoral Thesis, Orta Doğu Teknik Üniversitesi Sosyal Bilimler Enstitüsü, Ankara.

Büyüköztürk, Ş., Kılıç Çakmak, E., Akgün, Ö. E. Karadeniz, Ş., \& Demirel, E. (2009). Bilimsel araştırma yöntemleri. Ankara: Pegem Akademi.

Cerit, Y. (2008). Öğretmen kavramı ile ilgili metaforlara ilişkin öğrenci, öğretmen ve yöneticilerin görüşleri. Türk Ĕ̆itim Bilimleri Dergisi, 6(4), 693-712.

Çelik, T. (2013). Dil ve edebiyat öğretimi. Ankara: Anı Yayıncılık.

Danesi, M. (2017). The bidirectionality of metaphor. Poetics Today, 38(1), 15-33.

Dinçel, B., \& Yılmaz, A. (2018). Ortaokul öğrencilerinin ve Türkçe öğretmeni adaylarının “Türkçe dersi” ve “Türkçe öğretmeni” kavramlarına ilişkin metaforları. Türkiye Sosyal Araştırmalar Dergisi, 22(1), $243-276$.

Erten, N. B. (2008). Ortaöğretimde dilbilgisi dersine yönelik öğrenci tutumlarına dair metaforların söyledikleri, I. Uluslararası Türkçe Ĕ̆itimi ve Öğretimi Sempozyumu, Gazi Mağusa-Kıbrıs.

Gibbs, R. (1994). The poetics of mind: figurative thought, language and understanding. Cambridge: Cambridge University Press.

Inbar, D. (1996). The free educational prison: metaphors and gmages, Educational Research, 38 (1), 77-92.

İpşiroğlu, Z. (2002). Türkçe yazın eğitimi nasıl çağdaşlaşacak?, Nasıl bir edebiyat eğitimi? Edebiyat eğitimi çalıştayı. İstanbul: Özgür Matbacılık.

Johnson, M. (1987). The body in the mind. Universtiy of Chicago Pres.

Kapanadze, D., \& Kaya, T. (2019). 11. sınıf öğrencilerinin Türk dili ve edebiyatı dersinde uygulanan söylem çözümleme yöntemine ilişkin görüşleri. Kastomonu Ĕ̆itim Dergisi, 27(1), 347-364.

Kamberi, L. (2014). Using metaphors in language teaching and learning, European Journal of Research on Education, Special Issue: Contemporary Studies in Education, 92-97.

Kavcar, C. (2017). Edebiyat ve eğitim. Ankara: Anı Yayıncılık.

KKTC MEB (2006). Kıbrıs Türk Edebiyatı. Lefkoşa.

Koç, E. S. (2014). Sınıf öğretmeni adaylarının öğretmen ve öğretmenlik mesleği kavramlarına ilişkin metaforik algıları. İnönü Üniversitesi Ĕ̆itim Fakültesi Dergisi, 15(1), 51-72.

Lakoff, G., \& Johnson, M. (2005). Metaphors we live by. (G. Y. Demir, Trans.) İstanbul: Paradigma Yayıncılık.

Levine, P. M. (2005). Metaphors and images of classrooms. Kapa Delta Pi, 41(1), 172-175. 
Miles, M.B., \& Huberman, A.M. (1994). Qualitative data analysis: an expanded sourcebook. London: SAGE Publications.

Miles, M.B., \& Huberman, A.M. (2015). Nitel veri analizi. (S. Akbaba Altun, A. Ersoy, Trans. Ed.). Ankara: Pegem Akademi.

Miller, S. I. (1987). Some comments on the utility of metaphors for educational theory and practice. Educational Theory, 37, 219-227.

Modell, A. H. (2009). The metaphor-the bridge between feelings and knowledge, Psychoanalytic Inquiry, 29, 611.

Morgan, G. (1998). Yönetim ve örgüt teorilerinde metafor. (G. Bulut, Trans.) İstanbul: Bzd Yayıncılık.

Ŏguz, A. (2005). Öğretmen eğitim programlarında metafor kullanma. XIV. Ulusal Ĕ̆itim Bilimleri Kongresi, Pamukkale Üniversitesi Ĕ̆itim Fakültesi, 28-30 Eylül, 1-8.

Oral, B., \& Aşılığlu, B. (2000). Lise Türk dili ve edebiyatı dersi öğretmenlerinin Türk dili ve edebiyatı programı hakkındaki görüşlerinin değerlendirilmesi. Eğitim ve Bilim, 25 (116), 34-41.

Palic, G. S., \& Durukan, U.G. (2018). Determining the perceptions of teacher candidates on the concepts of science course, science laboratory, science teacher and science student via metaphors. International Journal of Research in Education and Science (IJRES), 4(2), 436-453.

Pehlivan, A. (2007). Turkish Cypriot literature course in emerging cultural and educational policies. L1 Educational Studies in Language and Literature, 7(2), 35-51.

Pehlivan, A. \& Aydın, S. (2010). Türkçe öğretmeni adaylarının 'öğretmen' ve 'öğrenci' kavramına ilişkin kulland1kları metaforlar. Turkish Studies, 5 (3), 818-842.

Pehlivan, A. (2018). Medium of instruction policies: Turkish Cypriots and their reflections on instructional technologies. EURASIA Journal of Mathematics, Science and Technology Education, 14(5), 1683-1693.

Saban, A. (2004). Giriş düzeyindeki sınıf öğretmeni adaylarının öğretmen kavramına ilişkin ileri sürdükleri metaforlar. Türk Ĕ̆itim Bilimleri Dergisi, 2(2), 135-155.

Saban, A., Koçbeker, B. N., \& Saban, A. (2006). An investigation of the concept of teacher among prospective teachers through metaphor analysis. Educational Sciences: Theory E Practice, 6 (2), 509-522.

Saban, A. (2009). Öğretmen adaylarının öğrenci kavramına ilişkin sahip oldukları zihinsel imgeler. Türk Ĕğitim Bilimleri Dergisi, 7(2), 281-326.

Sever, S., Kaya, Z., \& Aslan, C. (2011). Etkinliklerle Türkçe öğretimi. İzmir: Tudem Yayıncılık.

Soysal, D., \& Afacan, Ö. (2012). İlköğretim öğrencilerinin “fen ve teknoloji dersi" ve "fen ve teknoloji öğretmeni" kavramlarına yönelik metafor durumları. Mustafa Kemal Üniversitesi Sosyal Bilimler Enstitüsü Dergisi, 9(19), 287-306.

Vadeboncoeur, J. A., \& Torres, M. N. (2003). Constructing and reconstructing teaching roles: a focus on generative metaphors and dichotomies. Discourse: Studies in the Cultural Politics of Education, 24 (1), $87-$ 103.

Wells, Ş. Y. (2015). Görsel sanatlar öğretmeni adaylarının öğretmen ve sanatçı algısına ilişkin metafor analizi, Hacettepe Üniversitesi Ĕ̆itim Fakültesi Dergisi, 30(3), 160-175.

Yıldırım, A., \& Şimşek H. (2011). Sosyal bilimlerde nitel araştırma yöntemleri. Ankara: Seçkin Yayıncılık. 
Yılmaz, F., Göçen, S., \& Yılmaz, F. (2013). Öğretmen adaylarının öğretmen kavramına ilişkin algıları: bir metaforik çalışma. Mersin Üniversitesi Eğitim Fakültesi Dergisi, 9(1), 151-164. 